\title{
Politik Karikatürlerde Kadının Temsili: 1950 Seçimleri ve Nesneleştirilen Kadın
}

\author{
Didem Deniz
}

Uşak Üniversitesi, İletişim Fakültesi, Uşak.

\section{$\ddot{O} z$}

Karikatür, her ne kadar mizahi bir unsur olarak anılsa da içinden çıtı̆̆̆ toplumun politik, kültürel, toplumsal ve cinsiyete bağh eğilimlerini de yansitan ideolojik bir araçtır. Bu bağlamda hem siyasal iletişim aracı olarak hem de dönemin toplumsal yapısını yansıtması açısından oldukça önemli bir kaynaktır. 1950 Seçimleri çok partili hayattaki ikinci seçim olmasına rağmen yarattığı politik atmosfer ve iktidar-muhalefet çatışmasının hareketliliği açısından Türkiye'nin en önemli genel seçimlerinden biridir. Dönemin en önemli siyasal iletişim aracı olan gazeteler hem bir haber mecrası hem de yaşadığ̆ dönemdeki toplumsal hayatı bize aktaran manipülatif birer aynadır. Bu anlamda gazetelerde çıkan her türlü öğe bize o dönemle ilgili önemli veriler de sunmaktadır. Erken cumhuriyet döneminin yarattığı kadın imajı batıll, eğitimli, modern giyimli ve cumhuriyetin militan savunucusu olarak kurgulansa da Türkiye'de kadınlar çoğu zaman toplumsal yapının edilginleştirilmiş, fedakâr, sadık ve makbul anne olan bireyleri olarak görülmü̈slerdir. Bu çalışma 1950 Genel Seçimleri çerçevesinde gazetelerde yayımlanan karikatürlerdeki kadınların politik konumlandırılışını ele almaktadır. Çalışma, dönemin önde gelen iki ulusal gazetesi olan Vatan ve Ulus gazeteleri ile İzmir'deki yerel gazetelerden Demokrat İzmir ve Yeni Asır gazetelerinin ana sayfalarında yayımlanan 1950 Genel Seçimine yönelik karikatürlerde resmedilen kadınların politik bir özne mi yoksa bir nesne mi olduğunu eleştirel söylem analizi yöntemiyle çözümlemeyi amaçlamaktadır. Bu araştırmadan elde edilecek verilerle hem o dönemdeki kadının kamusal ve politik alandaki yerinin anlaşılmasına katkı sağlanması hem de politik karikatür araştırmalarına ışık tutulması hedeflenmektedir.

Anahtar Kelimeler: Politik Karikatür, 1950 Genel Seçimleri, Kadının Temsili

\section{Representation of Women in Political Caricatures: The 1950 General Elections and the Objectified Woman}

\section{Abstract}

In addition to being humorous, caricatures are also a tool that reflects political, cultural, social, and gender related intentions of the society from which they emerge. In this sense, caricatures are important both as a political communication tool and as a source that reflects the social structure of the period. Although 1950 Elections was the second election within the multiparty system, it is one of the most significant general elections in Turkey in terms of the political atmosphere and the government-opposition conflicts it created. Newspapers, being the most important political communication tool of the period, have been both the channel for news and at the same time, manipulative mirrors that present us the social life of the period. In this respect, every item on the newspaper presents us important data concerning that period. In spite of the fact that the woman image created by the early republican period was portrayed as educated, in modern outfit and as the militant defender of the republic, in Turkey, women have usually been considered as the passive, devoted, faithful and acceptable mother individuals of the social structure. This study examines the political positioning of women in the caricatures that were published in the newspapers concerning 1950 General Elections. The study aims to find out whether women were 
presented as a political object or subject in the caricatures related with 1950 General Elections through critical discourse analysis. The caricatures chosen were published on the front pages of the two prominent national newspapers of the period, Vatan and Ulus along with two local newspapers from İzmir, Demokrat Izmir and Yeni Asir. It is aimed that the data obtained from this research will contribute both to the identification of the position of women in public and political spheres in that period and to political caricature studies.

Keywords: Political caricature, 1950 general election, the representation of women.

\section{Giriş}

Çoğu zaman eğlenme amaçlı yaklaştığımız karikatürler akademik araştırmalar açısından son yıllarda oldukça popüler hale gelmiştir. Özellikle görsel sanatlar, eğitim ve iletişim bilimleri alanlarında son yıllarda karikatür ile ilgili akademik çalışmalar sıklıkla üretilmektedir. Karikatür Türk Dil Kurumu'na göre "insan ve toplumla ilgili her tür olayı konu alarak abartılı bir biçimde veren, düşündürücü ve güldürücü resim" anlamını taşıyan karikatür, çoğu zaman hiciv ve eleştiriyle de birlikte anılmaktadır. Karikatür güç ve güce sahip olan kesimlerin diğerleri üzerine uyguladığı baskıyı hedef olarak belirlemektedir. Bu yüzden güç ve baskının olduğu ortamlarda eleştirel yapı ile donatılmış olan karikatür muhalif, sorgulayan ve hesap soran yapısıyla bir direniş yaratmaktadır. Karikatürün bu özelliği onu politik güçle her zaman bir çatışma durumuna sokmaktadır (Erdem, 2007: 182).

Karikatürün çatışmacı ve eleştirel tutumu gazetelerde farklılık göstermekte ve gazetelerin politik görüşüne göre şekillenmektedir. Birçok gazete kendisine yakın bulduğu siyasileri yüceltirken tarafı olmadıklarını yermiş, çoğu zaman bunu da karikatürler aracılığıyla yansıtmıştır. Gazetelerdeki bu durum, gerçeklik, doğruluk ve etik açısından farklı bir şekilde değerlendirilebilir. Ancak bu çalışma gazetelerde yer alan karikatürlerdeki kadın ve politik yaşam ilişkisi üzerinden hareket etmektedir.

Gazetelerde yer alan karikatürlerin ataerkil sistemin yansımalarını içselleştirdiği görülmektedir. Kadınların politik konuşmalarda daha az görüldüğü karikatürlerde, cinsiyet ayrımcılığına da denk gelmek mümkündür. Ülke kadınlarının toplumsal ve siyasi tarihine karikatürler üzerinden bakmak gazetelerin tutumu ölçeğinde dönemin dinamiklerini ve toplumsal kodlarını çözebilmek açısından da yardımcı olacaktır.

\section{Karikatürün Politik İşlevi}

Karikatürün yapısı onu eleştirel bir araç olarak görmemizi sağlasa da karikatürün günlük gazetelerde kullanımı biraz farklılık göstermektedir. Karikatürler genellikle gazetenin ideolojisi tarafından şekillenmekte, o gazetenin haberlere bakış açısını yansıtmakta ve çoğu zaman da siyasal gelişmelere ideolojik bir anlam katmaya çalışmaktadır. Streicher'in dediği gibi karikatür, günlük haber sunumlarını anlamlandırarak tamamlamak adına önemli bir yardımcıdır (Streicher, 1967). Bu anlamda gazetelerin özellikle ana sayfalarında yer alan karikatürler gazetelerin ideolojik yapısına veya yönelimine göre gündemin tekrar ele alındığı alanlar olarak karşımıza çıkmaktadır. Bazen editoryal karikatür adıyla da anılan bu tür karikatürler, 
yazı işleri ve/veya genel yayın müdürünün istekleri/yönlendirmesi doğrultusunda çizilmektedir (Şenyapılı,2003:107).

Toplumdaki yanlışlıkları, eksiklikleri ya da çarpıklıkları okuyucusuna ileten karikatür (Şenyapıl1,2003:15) doğal olarak politik güçle çatışma halindedir. Türkiye'de de karikatür çoğu zaman muhalif bir araç olarak üretilmiştir. Hatta 1946-1950 dönemleri arasında muhalefet partisi olan DP'yi eleştiren karikatür dergileri kapanmak zorunda kalmıştır. 1948 yılında 13 yıllık "Karikatür" dergisi 1949 yılında ise iktidar yanlısı Akbaba dergisi iktidarı eleştirmemeleri nedeniyle ortaya çıkan tiraj sıkıntısı yüzünden kapanmıştır (Öngören, 1998: 91). Türk karikatürünün bu noktaya gelmesinde belki de en büyük etki çok partili hayata geçiştir. 1946'dan sonra yaşanan gelişmeler karşısında karikatür daha da güçlenmiş, özgür ve etkin bir sanat niteliği kazanmıştır (Balcıoğlu ve Öngören, 1973: 7).

Ele aldığımız dönem içerisinde karikatür henüz çok da eski olmayan bir görsel alan iken aynı zamanda Türkiye'de var olan mizahın da dikkat çeken bir sunumudur. ${ }^{1}$. 1950'ler Türkiye'de her anlamda farklı bir dönemi temsil etmekle birlikte karikatür anlaminda da dünya örneklerinden farklılaşan bir zaman dilimini ifade etmektedir. Tan Oral bu dönemdeki karikatürleri dünya karikatüründen "farklı örnek"ler olarak değerlendirmektedir:

“Modern karikatürün Türkiye'de ve dünyada çıktığı 1950'li yıllarda Batı'daki editoryal, siyasi karikatürün dışında, Chaval gibi pırıl pırıl şeyler var, karşılı̆̆ında da Türkiye'de Turhanlar, Ferruhler vesaire, onların yarattığı modem karikatürün çok güzel örnekleri patlıyor. Fakat Türkiye'de ayn tarihlerde bir de demokrasi mücadelesi gibi sıkıntılı bir durum var. Dolayısıyla o modem karikatürü çizenler aynı karikatürü siyasal alanda da kullanmak zorunda kahyorlar ve bu, dünyada pek eşi olmayan çok ilginç sonuçlar çıkartıyor. Batı'da çizilen bir siyasi karikatür gün geçtikten sonra etkisi kalmayan bir şey, ama Türkiye'de siyasi olarak kullanılan, çok iyi etki yapan bir karikatür, o siyasi neden ortadan kalktıktan sonra da karikatür olarak hâlâ değer kazanmaya devam ediyor. Türk karikatürü diye çok garip bir şey oluşuyor. O yıllarda Türk karikatürü dünyada her yarışmada ödül almaya başladı, çünkü çok garip, yeni bir örnekti"(Çeviker'den aktaran Şenyapil1, 2003: 108-109)

Ancak yine de editoryal karikatürlerde çoğu zaman bu özgünlük görülmemektedir. Dönemin gazete karikatürleri sözsüz olarak çizilmekte ve gazete sahipleri ya da müdürleri tarafından sözlü metin eklenerek tamamlanmaktadır. Resmedilen şey genellikle iki kadın, iki yaşlı adam veya memur, iki çocuk gibi iki kişiden ibarettir. Çoğunlukla bu ikili kişiler iki erkekten oluşmaktadır. Erkeklerden biri gazete okurken çizilirken, diğeri de arkadaşının okuduğuna cevap vererek gazete sahibinin düşüncelerini dile getirmektedir (Balcıoğlu ve Öngören, 1973: 8). Bu karikatürün bağımsızlığı ya da araçsallaştırılması açısından farklı bir çalışmada

\footnotetext{
${ }^{1}$ Daha ayrıntılı bilgi için bkz. Öngören, F. (1998). Türk mizahı ve hicvi. Ankara: Türkiye İş Bankası Yayınlar1.
} 
değerlendirilebilir. Ancak gazete gibi politik metinlerin yer aldığı bir mecrada, karikatürlerin çoğunda erkeklerin yer alması ve ağırlıklı olarak erkeklerin konuşturulması politik alanın çoğu zaman erkek elinde olduğunun karikatürler aracılığıyla da yeniden üretildiği anlamına gelebilmektedir.

Karikatürün hücum etme ya da hicvetme işlevi gazetelerdeki konumları nedeniyle bağımsızlığını yitirmektedir. Diğer bir söyleyişle gazetelerdeki tarafgir yapı bu mecrada yer alan karikatürleri de etkilemiş, hicvetmedeki bağımsızlığını yitirmesine neden olmuştur.

\section{Ataerkiye Karşı Mücadele Bağlamında Kadının Benlik İnşası ve Temsili}

Kadın sorunları, kadın olmak ya da toplumsal cinsiyet meselesi genellikle toplumsal açıdan ataerkil sistemin yarattığı sıkıntılar çerçevesinde ele alınmaktadır. Tarihsel süreç içerisinde yok sayılan, ikinci plana itilen ya da ötekileştirilen kadınların mevcut ataerkil toplumsal düzenle kavgalı olması da bu sebeple kaçınılmaz duruma gelmektedir. Kadının geçmişten günümüze sürekli bir nesneleş(tir)meye karşı kendini özne olarak yaratma mücadelesi özellikle feminizmin ana temalarından biri olmuştur. İnsan hakları mücadelesinin sivil ve siyasi haklar üzerinden şekillenmesi kadınların mücadelesinin de başlangıcını oluşturmuştur.

Birinci dalga feminizm içerisinde yer alan ve 1848 yılında yayınlanan Declaration of Sentiments (Duygular Bildirgesi), kadın mücadelesinin ilk örneklerinden biri olmakla birlikte doğal haklara yaptığı vurguyla dönemin doğal haklar savunucusu olan erkeklerin de kendileriyle çelişkiye düşmesini sağlamıştır. Bu metinle birlikte radikal feminizmin de temelleri atılmaya başlanmıştır. Kadınların bir sınıf ya da bir grup olarak tarih boyunca devam eden ikincilliklerinin ve sistematik ezilmelerinin failinin erkekler olduğunu ortaya koyan bu metin, kadınlara uygulanan baskının patriarkal sistemden doğduğunu vurgulamaktadır (Donovan ,2014: 31).

Kadının özel alandan çıkıp kamusal alanda kendine yer bulması ve politik bir varlık olarak kendini gösterebilmesi, uzun ve çok taraflı bir mücadelenin sonucu olarak karşımıza çıkmaktadır. Yasalar önünde eşitlik söylemi kadını siyasal alanda özneleştirmediği gibi eril yapının da bu söylem arkasına sığınmasına neden olmuştur. Fransız Devrimi krala karşı özgürlük ve cumhuriyet mücadelesi iken, bu mücadelenin erkekler tarafından erkekler için kazanıldığı düşüncesi dönem çağdaşlarının birçoğu tarafından benimsenmiştir. Bu sebeple kadınların bir hak mücadelesine girmesi çok da kabullenilmemiştir. Sledziewski'ni kullanacak olursak; "kadın vatandaşları siyasal topluluğa kabul etmek, karar almalarına, erkeklerle eşit temelde devrimin aktif özneleri olmalarına olanak vermekti. Birçok çağdaş için bu, hoş görülemezdi. Aksine, erkeklerin kadınları kurtaracak medeni kanunlar çıkarmaları gerektiği düşüncesi daha rahatlatıcıydı; çünkü bu durumda kadınlar, nesne konumundaydılar: Kuşkusuz, ilerici yasaların nesnesi, fakat yine de nesne"dir (Sledziewski, 2005: 44). Bu tarihsel gerçek, kadın mücadelesinin asıl olarak kadınlar için ve kadınlar tarafından yapılması gerektiğini göstermektedir.

Ataerkil iktidarın sahip olduğu düşünce yapısı sadece erkeklerin kadınlar üzerindeki egemenliğini kurmamakta, aynı zamanda kadınların bu egemenliğe karşı 
rıza göstermesiyle ataerkilliğin kadınlar tarafından bir anlamda koruma altına alınmasını da sağlamaktadır. Bu yüzden feminizmin verdiği mücadele yalnızca erkeklere karşı değil ataerkil sistemin hegemonyasına rıza gösteren kadınlara da karşıdır. Kadının benliğini bulması ve kadın/özne olduğunu fark etmesi bu mücadele alanındaki en anlamlı başarılardan biri olmaktadır.

Touraine'e göre "ben bir kadınım" demek, kadının kendisi olma ve kendi seçtiği kimliğe istediği içeriği yükleme hakkına sahip olmasıdır. Bu sahip olma durumu aynı zamanda kadının özgürlügünün kendi kendine tanımlama, davranma ve değerlendirme yeteneğinin de kanıtıdır. Kadının kadın olduğunu ilan etmesi bu öznelik fethinin kanitlarıyla radikal bir olumlamadır. Geçmişte dinbilimcilerin ruhu olduğundan bile şüpheye düştüğü kadınlar artık özgür, sorumlu, düşünen ve kendi benliğini yaratan kadınlardır. Dışarıdan dayatılmış anlamlarla yüklü nesne olmaktan çıkan kadın kendi özneliğini yaratmayı amaçlamaktadır (Touraine , 2007 : 43-44).

Higonnet'e göre kadınların tasarım alanında kendi tasvirlerini çizmeleri ya da başkaları tarafından tasvir edilmeleri kendilerini, vücutlarını ve toplumdaki yerlerini öğrenmeleri ve bu konuda yeni tutumlar geliştirmeleri için önemli ve heyecan vericidir (Higonnet, 2005 : 364). Kadınların artık kendilerini tarihin bir nesnesi değil de öznesi olarak görmeleri sanattan edebiyata, siyasetten ekonomiye, özel alandan kamusal alana kadar hemen her yerde kendi varoluşlarını kabul etmeleriyle gerçekleşebilecektir.

Günümüzde kadınlar -özellikle üçüncü kuşak feminist hareketle birlikte- özne olmanın bilinci ile hareket etmektedir. Bu alan Simone de Beauvoir, Kate Millett, Judith Butler gibi düşünürlerle daha zenginleşmiş görülmektedir. Son dönem feministlerin bazıları toplumsal cinsiyete karşı her türlü ayrımcılığın sonlandığı ve hatta ataerkil sistemin yarattığı kurumların yeni baştan yazıldığı bir dünya arzularken, bazıları cinsiyetin ve cinsel türlerin kendi başlarına bir alan oluşturması gerekliliğini savunmaktadır. Durum ne olursa olsun, Touraine'nin de dediği gibi artık kadınlar özne olarak hareket etmek istemektedirler, kendilerini öyle görmekte ve bunun mücadelesini vermektedirler. Kadınlar toplumda özne fikrini ve toplumsal bilimlerde bunun getirdiği yönelim değişikliğini en bariz şekilde taşıyan kategoridir (Touraine, $2007: 63)$

Toplumsallaşma süreci bireyin dünyaya geldiği ilk andan itibaren başlar ve aile, çevre, eğitim, siyaset, medya gibi kurumlar aracılığılyla öğrenilir. Toplumda üstlendiğimiz ve uygulamak zorunda birakıldığımız toplumsal cinsiyet rolleri bu kurumlar aracılığıyla yeniden üretilir. Ancak değişim bu toplumsallaşma sürecini de derinden etkilemektedir. Özellikle feminizmin etkisiyle bireyin cinsiyete dair rolleri giderek değişmektedir. Medya çoğu zaman bu değişime paralel bir perspektifle hareket etse de bazen de değişimin çok gerisinde kalmakta ve eski cinsiyet kodlarını yeniden canlandırmaktadır².

\footnotetext{
2 Örneğin Hürriyet Gazetesi Aile içi Şiddete Son kampanyasını yürütmesine karşın, kadına karşı şiddet haberlerini genellikle üçüncü sayfada ve olgusal olmayan bir tarzda münferit olaylar olarak yazmaktadır.
} 
Kadın çalışmalarının medya üzerinde önemli bir etkisi vardır. Saktanber'e göre basının 1980'lerden itibaren feminist harekete ve kadınların sözüne yer vermeye başlamıştır (Saktanber, 1995: 214). Ancak yine de medya kadınların ataerkil sistem ile mücadelesinde kadınları cinsel obje ya da fedakar anne ideal eş olarak göstermeye devam etmektedir.

\begin{abstract}
"Sonuçta televizyonun kadın (hanım) programları kadınlar cinsellikleri güzellik, zerafet ve bakımlılıklarının dışında çă̆rıştırllmayan "iyi" anneler, "uyumlu" eşler ve kadınlikları her şeyin önünde tutulan meslek sahibi kadınlar olarak kurgularken, gazetelerin magazin ekleri bunlara ek olarak abartılı bir cinsellik sergileyen "serbest" ve hatta "sereserpe" kadinlara da bolca yer verir. Bunlar çoğunlukla evlilik kurumunu asla eleştirmeyen, ancak "evlilikle sanat hayatının bir arada yürümediğinden" yakman artist, şarkıcı veya mankenler olup, "cinsel çekicilikleri" dekolteleriyle sunulan "davetkâr" kadınlardır. Erkeklere çıkarılan bu davet diğer kadınlara da "cinsel cazibe"nin nasıl bir şey olduğunu göstermiş olur. Ancak cüretkâr bir çılaklık sergileme velveya frapan giysiler ve göz süzmelerle kurulan bu cinsel cazibenin getirilerinin yanında - para, şan, şöhretmaliyetlerinin neler olduğu da gösterilir: Kalpler hep boştur, son sevgiliden yeni ayrılmanın üzüntüsü büyüktür, toplumun baskılarından bunalımlara girilmiştir. Bu koşullar altında da olsa toplumda bir "isim" olmanın, bol para edinmenin özendiriciliğine karşı, bu tür şeylere özenip "kötü yola" düşmüş, cinayete kurban gitmiş veya "yuvası yıkılmış" kandırılmış kadınların haberleri de bu maliyetin diğer yüzünü oluşturur." (Saktanber, 1995: 219).
\end{abstract}

Kadınların 1950 Türkiye'sinde de tanıtımı bundan çok farklı değildir. Özellikle o döneme ait reklamlarda kadınların mutfak, güzellik ve annelikle idealize edildiğini görmekteyiz. 1950 yılında çıkan bir buzdolabı reklamında (bkz. Resim -1) mutfak önlüklü bir anne yine mutfak önlüklü olan kızına buzdolabı önerisinde bulunmaktadır. Aşağıda yer alan iki reklam görseli de kadınları klasik ataerkil sistem içerisinde "ideal anne", "mutfağı sahiplenen", "evini düşünen", "evlenmek ve yuva kurmak en büyük arzusu olan", "güzel" kadın sıfatları ile imgeleştirmektedir. Görülmektedir ki kadınlar çoğu zaman medyada - şimdi ki duruma benzer bir yapıda - fedakar bir ev kadını, ideal ve güzel bir eş, erkekleri cezbetmesi gereken ve mutluluğu böyle yakalayan kadınlar olarak resmedilmektedir. Medyanın, kadınları bir birey olarak görmek yerine ataerkil ideolojiye uygun çeşitli "sıfat"larla nesneleştirmesi, toplumsal algının da bu yönde pekişmesine neden olmuştur demek yanlış olmayacaktır.

Diğer yandan reklamlarda da kadın çoğu zaman mutfakta ve çocukları için fedakarlık yaparken gözlemlenmektedir.. 


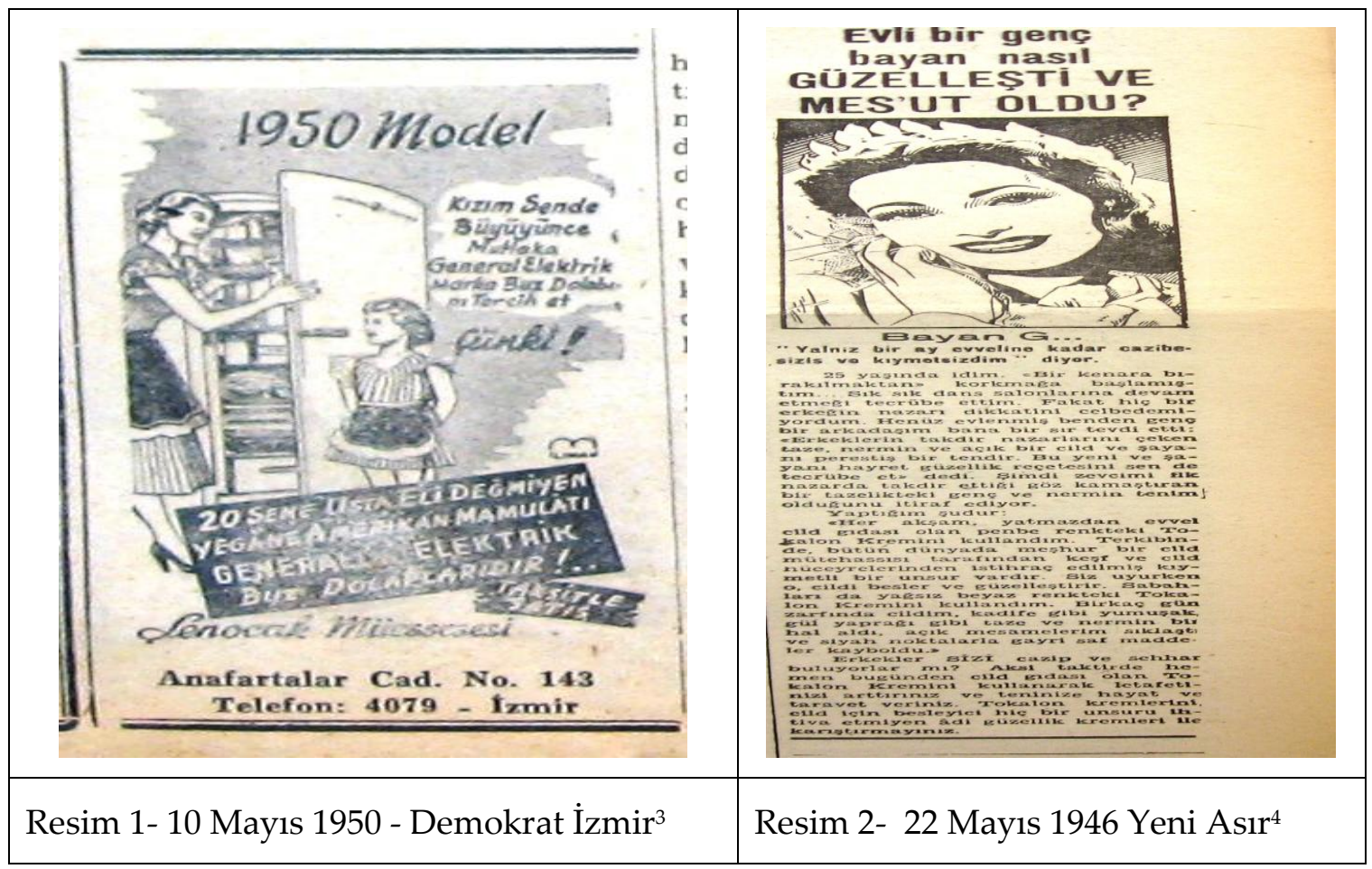

\section{Cumhuriyetin İlk Yıllarından Ellili Yıllara: Kadın ve Politikada Temsili}

Türkiye Cumhuriyeti kurulduğu andan itibaren batılılaşmayı ve modernizmi hedef olarak seçmekle birlikte sivil, siyasi ve sosyal haklar açısından da oldukça devrimsel adımlar atmıştır. Bu adımlardan birinin ana konusu da kadın hakları olmuştur. Bu gelişmeler Şirin Tekeli, Fatmagül Berktay, Deniz Kandiyoti gibi bazı akademisyenler tarafından kadın hareketinin ilerleyişine engel olan uygulamalar

\footnotetext{
${ }^{3}$ Resimde anne kızına "Kızım sende büyüyünce mutlaka General Elektrik Marka Buzdolabını tercih et" demektedir

${ }^{4}$ Evli bir genç bayan nasıl GÜZELLEŞTİ VE MESUT OLDU?

Bayan G....

"Yalnız bir ay evveline kadar cazibesiz ve kıymetsizdim " diyor.

25 yaşında idim. "Bir kenara bırakılmaktan" korkmağa başlamıştım.... Sık sık dans salonlarına devam etmeği tecrübe ettim. Fakat hiç bir erkeğin nazarı dikkatini celbedemiyordum. Henüz evlenmiş benden genç bir arkadaşım bana bir sır tevdi etti: "Erkeklerin takdir nazarlarını çeken taze, nermin ve açık bir cild ve şayanı perestiş bir tendir. Bu yeni ve şayanı hayret güzellik reçetesini sen de tecrübe et" dedi. Şimdi zevcimi ilk nazarda takdir ettiği göz kamaştıran bir tazelikteki genç ve nermin tenim olduğunu itiraf ediyor.

Yaptı̆̆ım şudur:

"Her akşam, yatmazdan evvel cild gıdası olan penbe renkteki Tokalon Kremini kullandım. Terkibinde, bütün dünyada meşhur bir cild mütehassısı tarafından keşf ve cild nuceyrelerinden istihraç edilmiş kıymetli bir unsur vardır. Siz uyurken o, cildi besler ve güzelleştirir. Sabahlan da yağsız beyaz renkteki Tokalon Kremini kullandım. Birkaç gün zarfında cildim, kadife gibi yumuşak, gül yaprağı gibi taze ve nermin bir hal aldı, açık mesamelerim sıklaştı ve siyah noktalarla gayri saf maddeler kayboldu."

Erkekler SİŻ cazip ve sehhar buluyorlar mı? Aksi taktirde hemen bugünden cild gidası olan Tokalon Kremini kullanarak letafetinizi arttırınız ve teninize hayat ve taravet veriniz. Tokalon kremlerini, cild için besleyici hiç bir unsuru İhtiva etmiyen âdi güzellik kremleri İle karıştırmayınız.
} 
olarak görülse de Nermin Abadan Unat, Leyla Kırkpınar gibi kadın çalışmaları yapan diğer akademisyenler Cumhuriyetin haklar açısından getirilerinin günümüz feminist hareketinin ilerleyişine ön ayak olduğuna vurgu yapmaktadır. Berktay'a göre, Türkiye'deki feminizm -Cumhuriyetten önce- Türk ulusçu ideolojisinin doğması ile paralel özellikler göstermektedir. O'na göre o dönemde kadın hareketinin özgül niteliğini ulusçu ideoloji oluşturmakta ve bu durum da kadınların bağımsız bir kimlik oluşturmalarını gölgelemektedir. Berktay, her ne kadar şeriatın egemen olduğu bir devlet yerine laik devletin feminist hareket için daha elverişli bir ortam hazırladığını dile getirse de Cumhuriyet Türkiye'sinin kadın haklarını araçsallaştırdığını ve kadının bu araçsallaşmada bir simge haline geldiğini söylemektedir (Berktay, 1998). Bu eleştirilerin temelinde Türkiye'de kadın hareketinin cumhuriyetle değil II. Meşrutiyetle birlikte canlandığı ve cumhuriyetin kurucu ideolojisinin kadın hareketini kendi ulus devlet düşüncesi içerisinde eriterek kadınları dışladığı düşüncesi yatmaktadır. Oysa cumhuriyet döneminin kadın hakları konusunda olumlu etkileri olduğunu düşünen Abadan-Unat'a göre ise cumhuriyeti kuran ideoloji, kadın haklarının gelişimi konusunda oldukça radikal kanunlara imza atmış ve kadınların eğitim, meslek ve kamusal alanda çalışma açısından erkeklerden geride kalmaması için çaba sarf etmiştir (Unat, 1998).

İster yeni cumhuriyetin kadın hakları ile ilgili atılımlarını olumlu açıdan değerlendiren bakış olsun ister bu adımların Türkiye'deki feminist hareketi baltaladığını düşünen görüş olsun, cumhuriyet ile birlikte kadınların hayatının özellikle kent ve siyasi hayatta önemli ölçüde değiştiğini söylemek mümkündür. Ancak bu değişimin gerek erkek dünyasında gerekse toplumsal hayattaki yansımasına aynı yönde etki edip etmediği tartışmaya açık bir konudur.

1950 yılına geldiğinde Türkiye önemli bir dönemeçten geçmektedir. Dünya Savaşı'nın bitmesi ve soğuk savaşın etkisini göstermeye başlaması ile çok partili hayata geçen Türkiye'de siyasi isimler de farklılaşmaya başlamaktadır. Kadınlara seçme ve seçilme hakkının tanınmasından sonraki süreçte oluşturulan ilk meclisteki kadın milletvekili sayısının giderek azalması ve kadın milletvekillerinin medyadaki görünürlügünün azlığ $1^{5}$ kadınların siyasal hayattaki etkisinin kamuoyu tarafından bilinmesine de engel olmaktadır.

Basındaki bu eksiklik erkek siyasilerin egemen güç olması ile de paralellik göstermektedir. Siyasal söylemdeki kadın milletvekili adaylığı tartışmaları aslında kadınların siyasal süreçte "öteki" olarak algılandıklarının da bir göstergesi olarak kabul edilebilir. Demokrat Partili Celal Bayar 1950 seçiminin hemen öncesinde İzmir'de yaptığı bir mitingde kadın siyasetçi adaylarının az olmasını eleştirenlere karşı;

"Deniliyor ki listelerimizde kadın namzet azmış. Kadın vatandaşlar, şüphe yok ki millî hayatımızda bir büyük varlıktırlar... Kadınların millî hayatta yer almaları, mevkî almaları, çalışmaları bir zarurettir. Fakat bunu adetle ölçmek... Bana asıl tuhaf görünen şey odur. Bir dâvanın prensibi kabul

\footnotetext{
${ }^{5}$ İncelenen gazetelerde haberi çıkan tek kadın siyasi Halide Edip Adıvar'dır
} 
edildikten sonra adet üzerinde durmanın ne mânası olur. Bir tarafta iki, diğer tarafta altı kadın... On altı olsaydı esas maksada ne derece tesir ederdi" (Yeni Asır, 10 Mayıs 1950)

sözleri ile karşılık verirken aslında kadınların siyasette olmasının amaçlarının gerçekleşmesinde negatif veya pozitif bir anlam ifade etmediğini dile getirmekte ve niteliğe vurgu yapmaktadır. Bayar her ne kadar nitelik açısından kadın katılımının önemine vurgu yapsa da geçen 67 yıl içerisinde kadınların siyasetle olan ilişkisi hep tartışılmıştır.

Dönemin Cumhurbaşkanı İsmet İnönü ise CHP'nin kadın aday sayısının fazlalığına vurgu yapmıştır.

"..., karşımdaki partilerin en ilerisinden üç defa daha fazla kadın aday göstermekle iftihar ediyorum. Bizim sarsılmayan kanaatimizce, kadınlarımıza, çalışma, cemiyetin mukadderatına iştirak etme imkânını ne kadar çok verirsek Büyük Meclisimizde ve bütün çalışma sahalarında hayat, o kadar insani ve şefkatli, ve aile meselelerine o kadar yakın olacaktır. Görüyorsunuz ki, cemiyetimizi ilerletmek gayretinde, Partimizle ideal yarışı yapmak kolay değildir. Kadın aday göstermenin bugünkü halimize göre güçlükleri, her parti için aynıdır. Mesele güçlükleri göğ̈̈̈leyecek idealin sağlamlığındadır" ( Ulus, 5 Mayıs 1950)

Bayar gibi İnönü de kadınların siyaset hayatlarını bir seçim konusu tartışması haline getirmiştir. Oysa bu bir tartışma konusu olmamalıdır. Kadınların insan olmasından kaynaklanan haklarından dolayı siyasetin doğal bir parçası olduğu gerçeği unutulmamalıdır. Ancak hem geçmiş hem de güncel tartışmalardaki "kadın siyasette nasıl ve ne kadar olmalıdır" sorusu soruldukça ve bu anlamda pozitif olarak düşünülen bir ayrımcılık yapıldığı sürece, siyasetin erkek hegemonyası altındaki bir alan olmasının engellenmesi ve kadınların politik açıdan temsil düzeylerinde önemli bir değişme olması da pek mümkün görünmemektedir. Bu algının oluşmasında elbette ki siyasal söylem ve toplumsal yapı oldukça etkilidir. Ancak toplumsal değişmenin en önemli faktörlerinden biri olan medyanın da bu anlamdaki rolü büyüktür. Özellikle ele aldığımız dönem içerisindeki en önemli kitle iletişim araçlarından biri olan gazetelerin kadını nesneleştiren ifade ve görsellere yer vermesi kadının toplumda özne olarak ön plana çıkmasını da engeller niteliktedir.

\section{Amaç ve Yöntem}

Bu çalışma Türkiye'nin çok partili hayata geçiş süreci içerisinde günlük siyasi gazetelerde yer alan karikatürlerin politik anlamda kadınları özne olarak görüp görmediklerini ele almaktadır. Bu ele alış aslında o dönem içerisinde toplumda yer edinmiş kadın algısının da dişavurumu olarak düşünülmektedir. Dönemin en yaygın iletişim araçlarından biri olan gazetelerin ana sayfasında yer alan karikatürler hem esprili bakış açısı hem de dikkat çekici bir görsel öğe olmaları açısından okuyucuya daha kolay erişebilmekte ve toplumsal algıyı da belirli ölçüde etkileyebilmektedir. 
Çalışma, dönemin önde gelen iki ulusal gazetesi olan Vatan ve Ulus gazeteleri ile İzmir'deki yerel gazetelerden Demokrat İzmir ve Yeni Asır gazetelerinin ana sayfalarında yayımlanan 1950 Genel Seçimine yönelik karikatürlerde yer alan kadınların politik temsillerini ele almaktadır.

Karikatür analizi aslında birçok açıdan yapılabilir. Estetik, düşünsel ya da göstergebilimsel açıdan karikatüre bakmak mümkündür. Ancak yine de karikatürü analiz edebilmek ve çözümlemesini yapabilmek birçok açıdan güçtür. Erdem'e göre "karikatürün dili ve bu dilin oluşturduğu karikatürün söylemini şekillendiren unsurları tanımlamak ve işlevlerini ortaya koymak gerekmektedir. Karikatürü oluşturan bu temel unsurlar, mizah (metafor, ironi ve hiciv), çizgiler (simge ve sembol) ve kullanılan alt yazılar (gazete haberleri ve deyimler) karikatürün çözümlenmesinde göz önünde bulundurulması gerekmektedir"(Erdem, 2007: 184). Karikatürün görsel ve düşünsel açıdan zengin olan zorlu iç yapısı onun analizini de farklı açılardan değerlendirme imkanı sunabilmektedir.

$\mathrm{Bu}$ çalışma karikatürleri hem bir görsel obje hem de bir metin olarak görmektedir. Bu açıdan karikatürlerin ne söylediği eleştirel söylem analizi yöntemi ile ele alınmıştır. Eleştirel söylem analizi metinleri anlamlandırmakta ve yorumlamaktadır. Metnin gerisinde saklı güdülere ya da metnin yorumundaki araştırma yönteminin seçimine ilişkin bilgileri ortaya çıkarma hedefindedir. Eleştirel söylem analizi; belirli bir soruya yanıt aramamaktadır. Bunun yerine ufkumuzu genişletmek, inanç, tutum ve davranışlarımız belirleyen söylemlerin varlığını ve iletisini tarihi ve sosyal bir bağlam içinde değerlendirme kaygısı gütmektedir. Eleştirel söylem analizinde değerlendirmeye tabi tutulan şeyler arasında söylemin dünyayı temsil eden bir sosyal uygulama olması; zaman, yer, sosyal, kültürel ve ideolojik bağlam içinde anlam kazanması, dilbilgisel özellikler ve yapıların bilinçli seçilmiş ya da seçilmemiş olmasına bakılmaksızın amaçlı olması, güç, direnme, yanlılık gibi sosyal uygulamaların temsil edilmesi ve bunların oluşumunun sağlanması yer almaktadır(Ülkü, 2004: 385) .

Bu çalışmada 1 Ocak -14 Mayıs 1950 tarihleri arasında yayınlanan Vatan, Ulus, Demokrat İzmir ve Yeni Asır gazetelerinin ${ }^{6}$ ana sayfalarında çıkan seçime yönelik 92 adet politik karikatür incelenmiş ve aralarından amaca yönelik örneklem ile seçilen kadın figürlerinin yer aldığı 14 adet karikatür analiz etmiştir. Gazeteler İzmir Ahmet Piriştina Kent Arşivi ve Müzesi'nde yer alan arşivden elde edilmiştir. Az da olsa sayıların bazıları eksik ya da deforme olmuştur. Bu arşivdeki eksik ya da deforme olmuş az sayıdaki karikatürlere erişilememiştir. Demokrat İzmir Gazetesinden 5, Yeni Asır Gazetesinden 2, Ulus Gazetesinden 3, Vatan Gazetesinden 4 karikatür kullanılmıştır. Karikatürlerin yanlarında o karikatürün özelliğine göre ardalan bilgisi, karakter tanımlama, bağlam ve tematik çözümleme gibi yorumlamalara yer verilmiştir. Analizin ikinci kısmında ise karikatürler tematik olarak ele alınmıştır.

\footnotetext{
${ }^{6}$ Analizde gazetelerin ideolojileri göz önünde tutulmamıştır. Ancak, Ulus Gazetesi ele alınan dönemde genellikle CHP yanlısı haber metin ve karikatürlere yer verirken, diğer gazeteler daha çok muhalif partiler ve DP'nin propagandasına yer vermiştir.
} 


\section{Araştırma ve Bulgular}

\section{Makro Çözümleme: Karikatürler ve Tanımlar}

Aşağıda gazetelerde çıkan karikatürler belirli bir sıra olmaksızın verilmiştir.

\begin{tabular}{|c|c|c|}
\hline No & Karikatür & Yayin Yer ve Tarihi \\
\hline 1 & 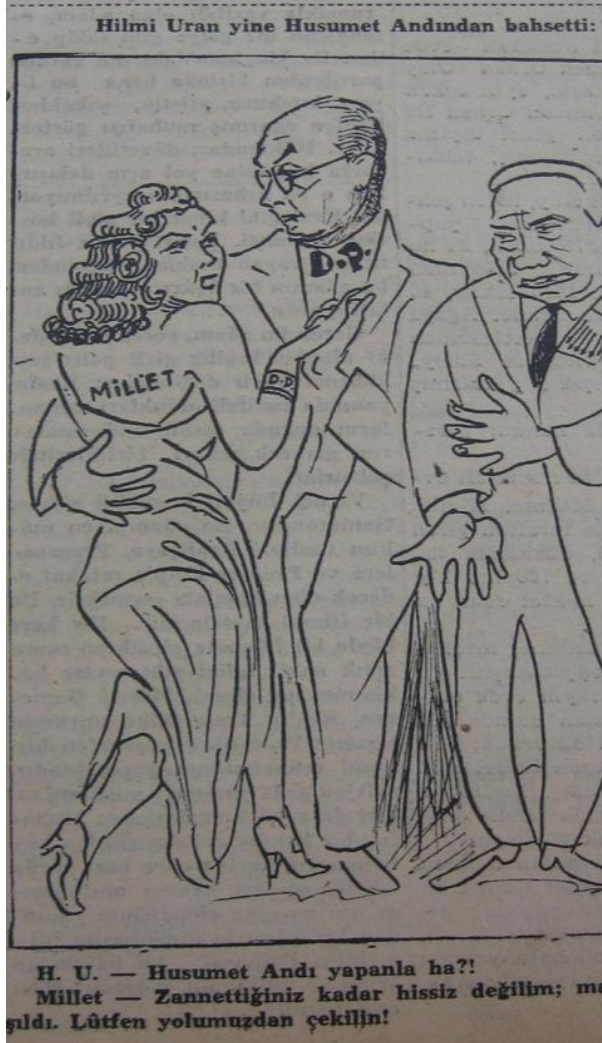 & $\begin{array}{l}\text { Demokrat İzmir } \\
3 \text { Şubat } 1950 \\
\text { Tanımlama: } \\
\text { - } \quad \text { Karikatürde } 3 \text { karakter } \\
\text { vardır: CHP'li Hilmi Uran } \\
\text { (Erkek/ Somut), DP'li Celal } \\
\text { Bayar (Erkek/Somut), } \\
\text { Millet (Kadın/Soyut) } \\
\text { - Güzel ve cazibeli bir kadın } \\
\text { için mücadele eden iki } \\
\text { erkek } \\
\text { - Davetkar kadın/ aldatan } \\
\text { kadın imajı }\end{array}$ \\
\hline
\end{tabular}




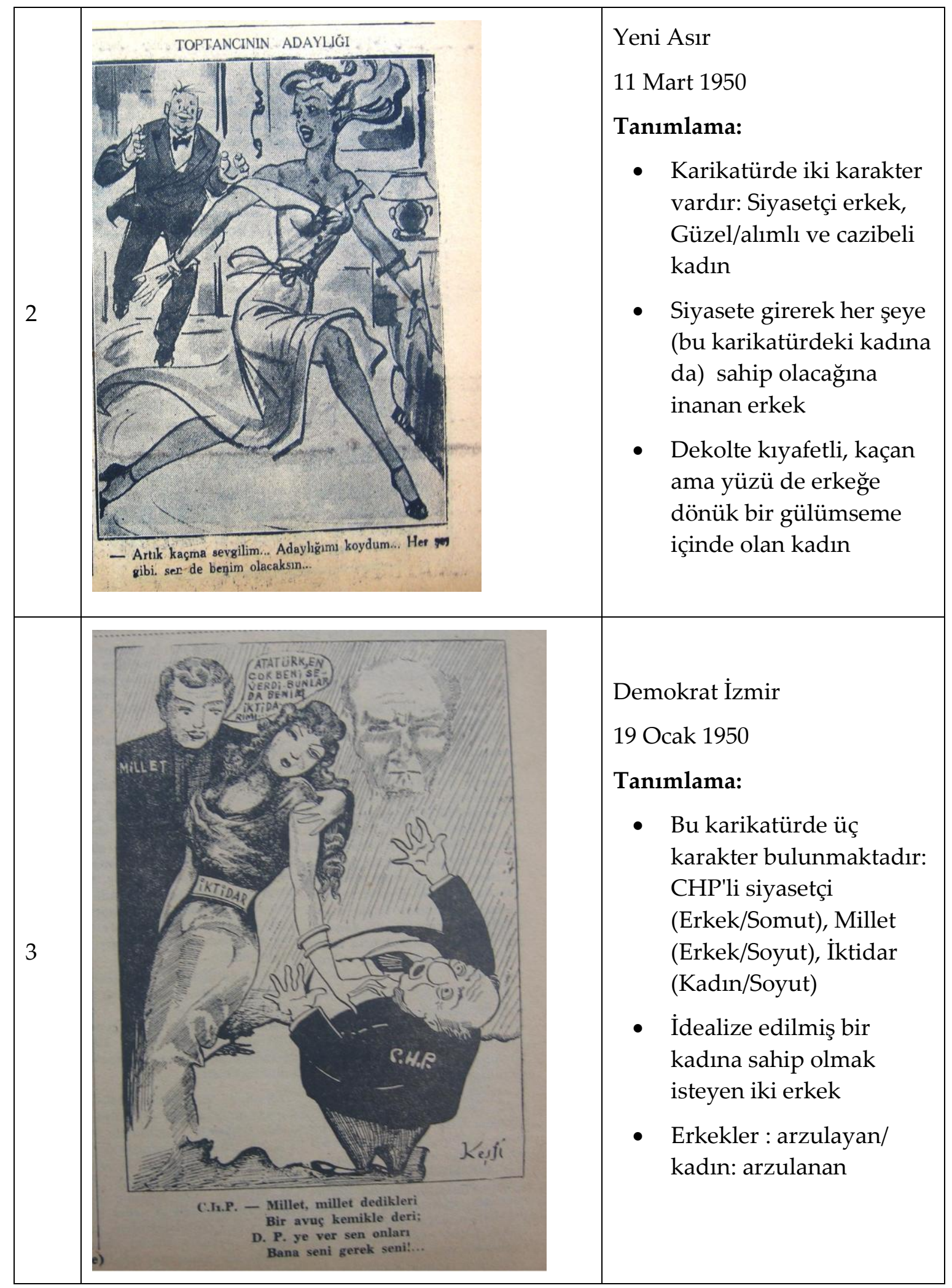




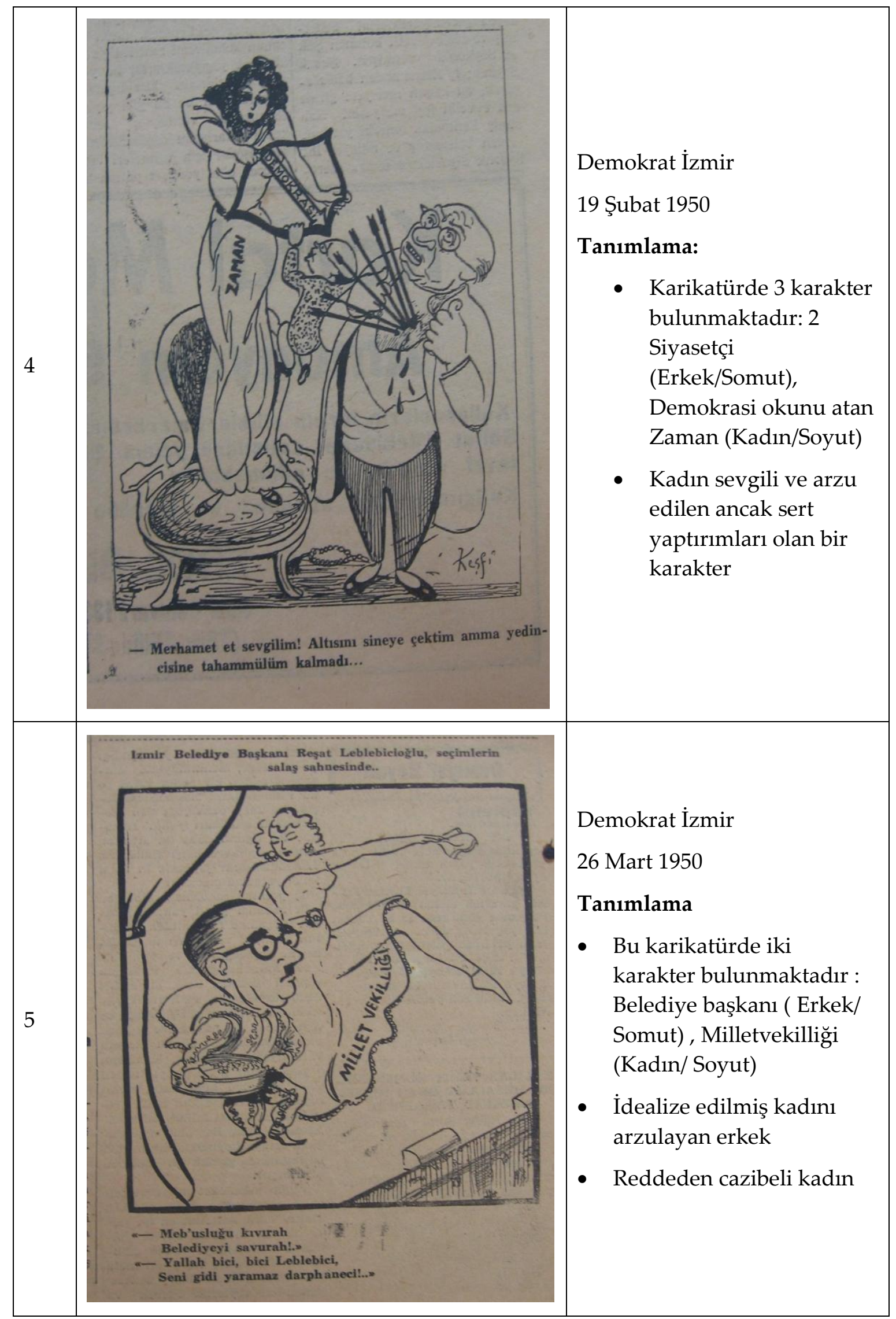




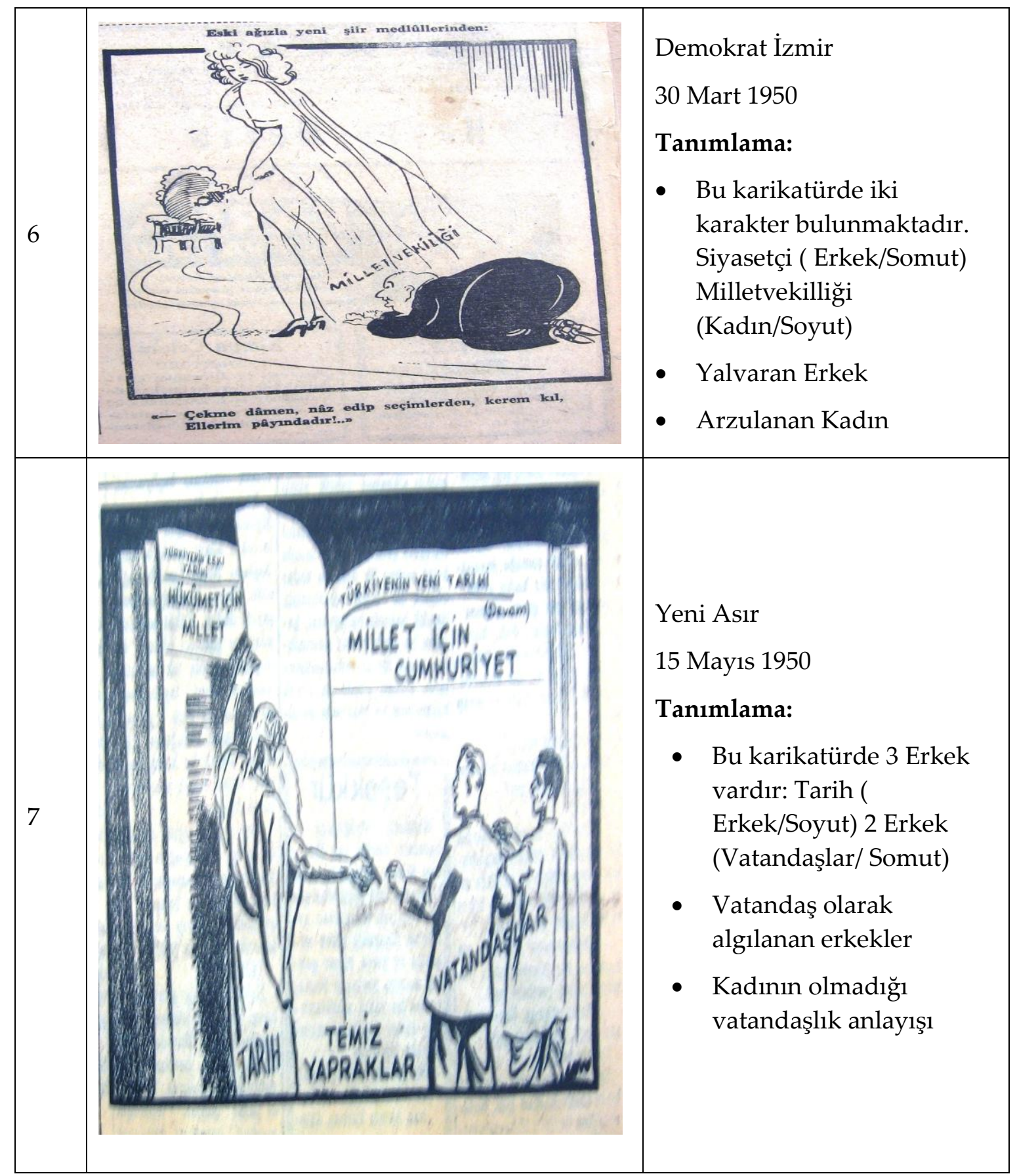




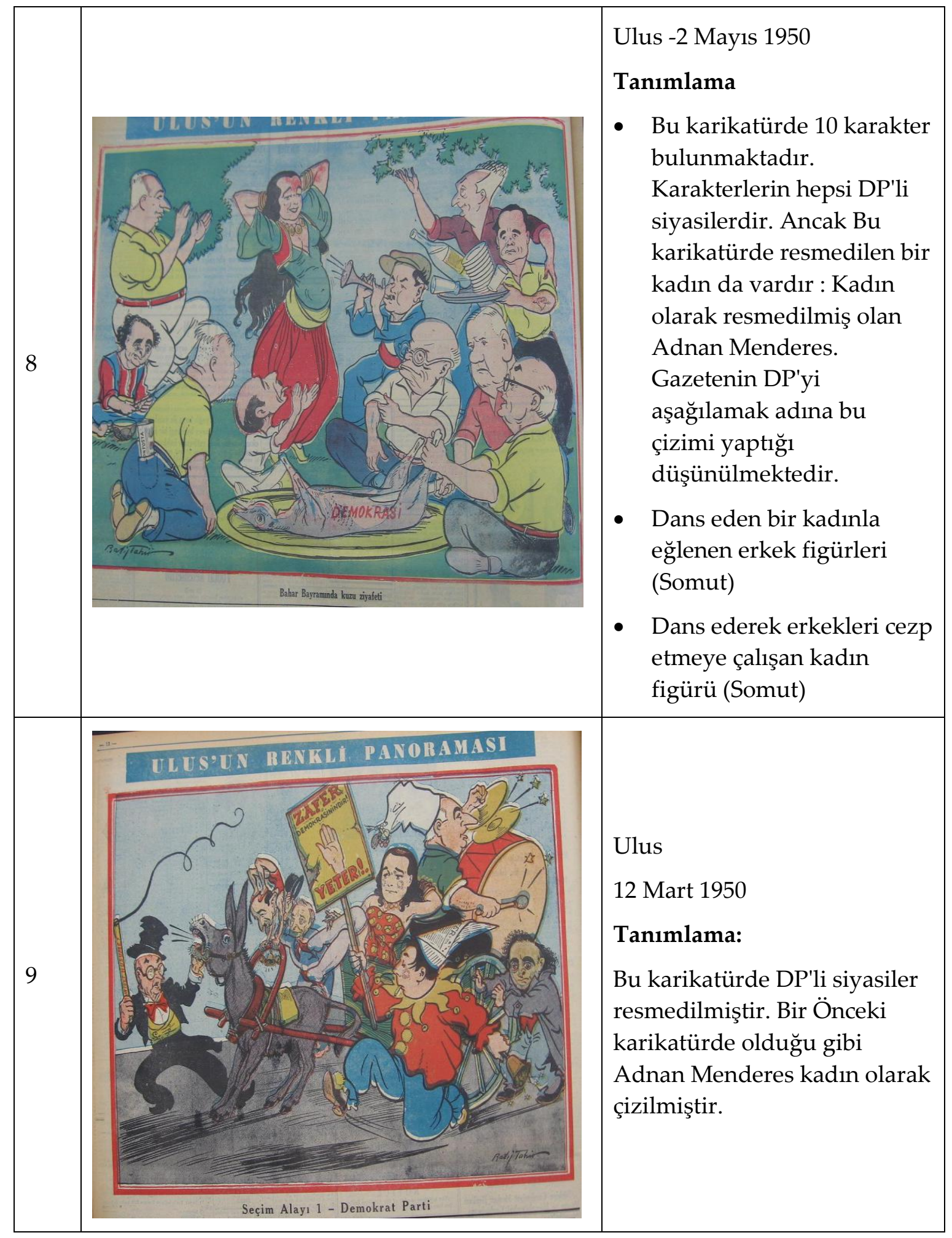




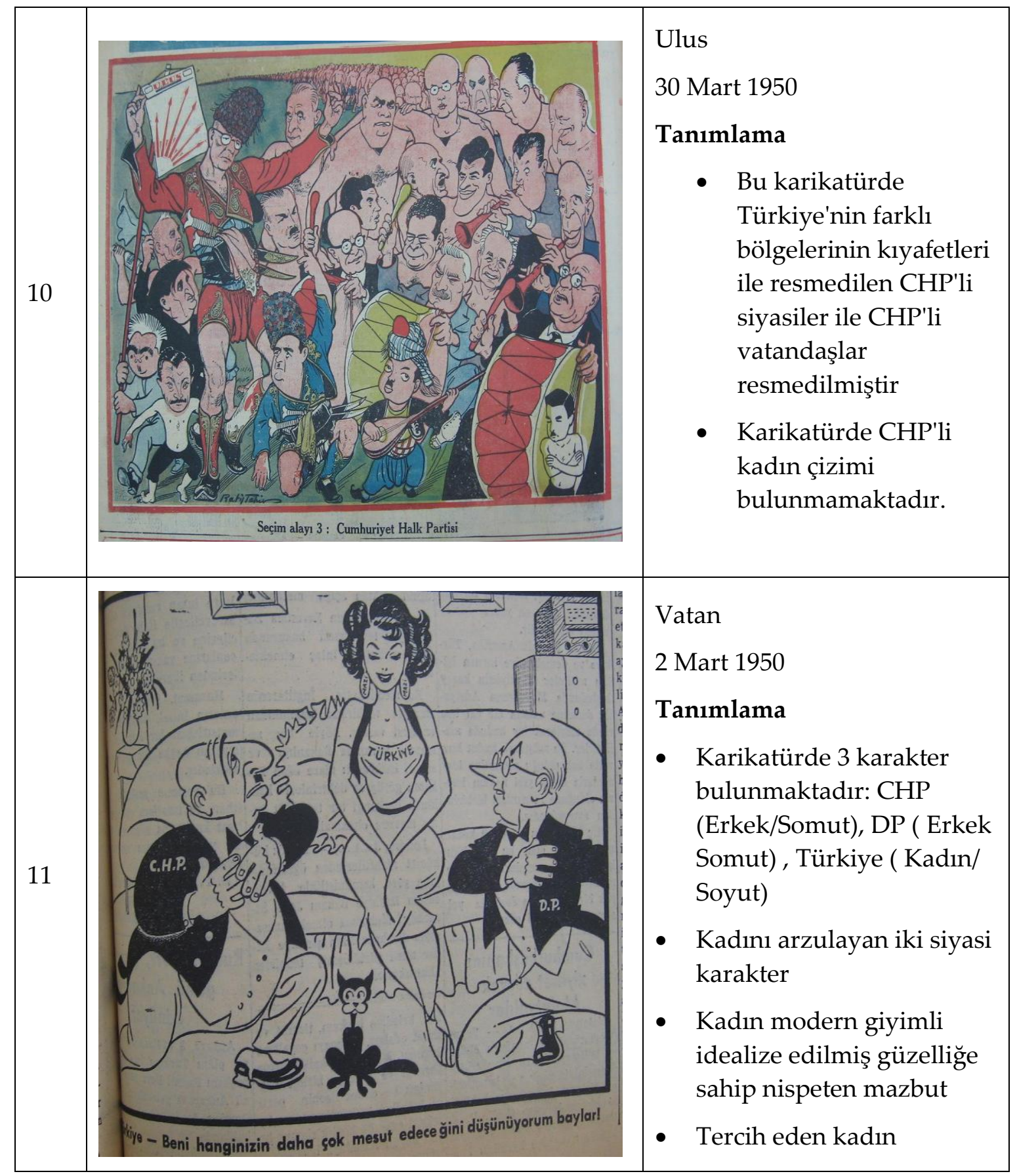




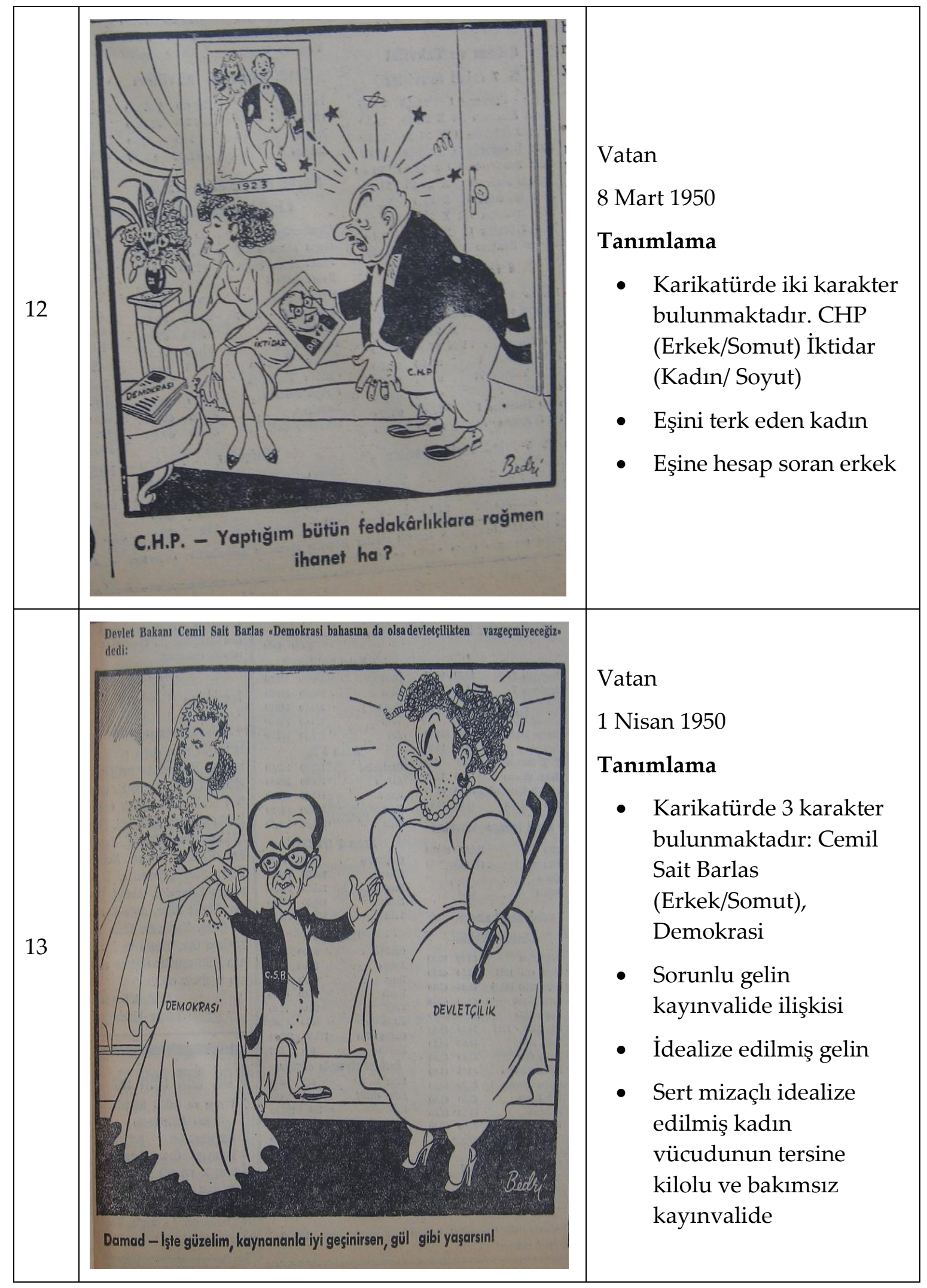




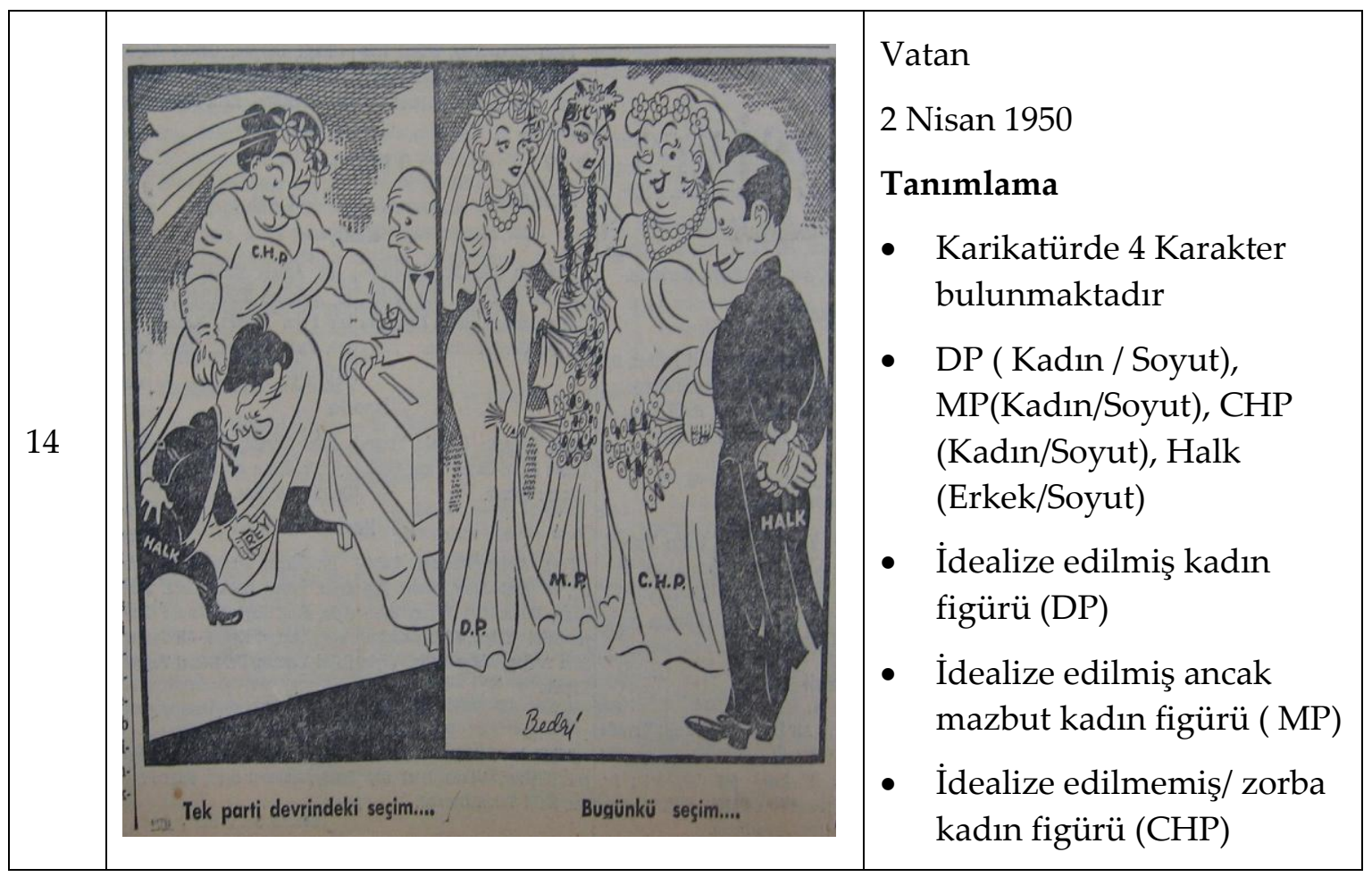

\section{Tematik Çözümleme:}

\section{Modern ve İdealize Edilmiş Güzelliğe Sahip Kadın}

Ele aldığımız karikatürlerin genelinde kadınlar kentlidir. Karikatürlerde genellikle modern giyimli, ideal güzellikte, medeni kanunla şekillenmiş evlilik hayatına sahip ya da olması düşünülen kadın çizimleri kullanılmıştır. Bu çizimlerin birçoğunda kadınlar konuşturulmamıştır. Diyalogu olan kadınlar ise siyasi söylemde bulunmamıştır.

Gazetelerin batılı/kentli kadın erkek tasvirleri, dönemin modern Türkiye anlayışı ile uyum içinde olduğunu göstermektedir. Ancak karikatürlerin alt metnine bakıldığında siyaset ve seçimler arzu eden ve edilen ilişkisi üzerinden anlatılmak istenmiştir diyebiliriz. Bu bağlamda arzu eden/isteyen ve bu haliyle aktif/etken olan erkekler ile arzu edilen/istenilen, pasif/edilgen kadın çizimleri ataerkil ideolojinin karikatürler aracılığıyla siyasette yansıması olarak açıklanabilir.

Karikatürlerde iktidar, millet, milletvekilliği gibi soyut kavramlar kadın olarak tercih edilmiş buna karşın eş bulma adayı/ ya da eşini kaybetmek istemeyen erkekler ise daha çok siyasi kimlik olarak yansıtılmıştır. Örneğin 5 ve 6 no'lu karikatürlerde kadın, milletvekili gibi somut bir figür değil; milletvekilliği gibi bir mevki/konumu ifade eden soyut bir simgedir. Bir başka örnek olan 1. ve 11. karikatürlerde ise erkekler, Türkiye ve milleti arzulayan ve onun kendisini tercih etmesini isteyen siyasetçilerdir.

Özetle ele alınan karikatürlerde ideal kadın imajı ile erkeklerin idealindeki arzu özdeşleştirilmiştir. Her ne kadar birçok karikatürde kadın tercih eden gibi gösterilse de bu tercih ediş sadece sandıkta olacaktır. Kadınların gazetelerde katılımcı 
ve çoğulcu demokrasinin aktif vatandaşları olarak değil de erkekler için idealize edilmiş arzular olarak tasvir edilmesi, politik hayatın ataerkil sistemin cinsiyet rolleri ile şekillendiğinin de bir göstergesidir.

\section{Aşağılanan Kadınlık}

Dönemin gazetelerinde yer alan ve burada örneklendirmediğimiz(sadece erkekler tasvir edildiği için) politik karikatürlerin çoğunda gündelik siyasi konular üzerinde genellikle erkekler konuşmaktadır. Kadınlar, yukarıda da bahsettiğimiz gibi karikatürlerde genellikle siyasetin kazanan/kaybeden ya da arzulanan/arzu eden kısmını betimlemede karşımıza çıkmaktadır. Bunun yanında kadınların farklı bir şekilde karşımıza çıkması, erkeklerin kadın olarak tasvir edilmesi gibi kadınlığın aşağılanması ve "estetik/ideal/şefkatli" tanımına uymayan kadınların istenilmemesidir.

Örneğin; Ulus gazetesinde yer alan 8. ve 9. karikatürlerdeki "çengi kadın" çizimi ile Vatan gazetesinde çıan 13. ve 14. karikatürlerdeki toplumda idealize edilmemiş kadınların tercih edilmeyeceği vurgusu ataerkil toplumda "istenilen" kadın tipini de bize yansıtmaktadır. Özellikle Ulus gazetesine ait karikatürlerde kadın olarak resmedilmiş Adnan Menderes figürü gazetenin erkekler için "kadınlığı" aşağılayıcı bir ifade olarak düşündüğünü göstermektedir. CHP yanlısı Ulus gazetesinin eleştirdiği Demokrat Partiyi aşağılamak amacıyla kullandığı bu çizim aslında Türkiye'deki erkek egemen ataerkil yapının kadını hala bir birey olarak görmekten uzak olduğunun da bir göstergesidir7.

Ele alınan karikatürlerin genelinde idealize edilmiş kadınlar görülmektedir. Ancak idealize edilmeyen kadınlara baktığımızda nispeten daha yaşlı/bakımsı//kilolu ve şefkatli olmayan kadın resimlerini görmekteyiz. Bu kadınlar genellikle CHP'yi temsilen çizilmiştir. CHP iktidarının uygulamalarını eleştirmek için toplumun kabul etmeyeceği düşünülen merhametsiz, bakımsız kadınların tercih edilmesi aslında toplumdaki ideal kadın algısının da sınırlarını göstermektedir. Her zaman bakımlı ve güzel olmak zorunda kalan, zayıf, fedakar ve şefkatli kadınlar gazetelere göre toplumun da arzuladığ kadınlardır.

\section{Nesneleşen Kadın}

Kadın olabilmek ve ben bir kadınım diyebilmek ve bu düşünceyle kamusal alanda olabilmek 1950 Genel seçimlerine giden Türkiye'deki gazete karikatürlerinde varlığını pek gösterememiştir. Ele aldığımız döneme ait karikatürlerde kadınlar siyasi bir özne değildir. Hatta kadınlar, siyasi özne olan erkeklerin arzu, ihtiras ve hırslarını belirginleştirecek nesneler olarak resmedilmişlerdir. Kadını elde etmek için savaşan erkekler, siyasal hayatın ana öğeleri iken kadınlar bu öğelerin soyut arzularıdır.

Özellikle 7. ve 10. karikatürler bize tüm bunların dışında başka bir şey daha anlatmaktadır. 7. Karikatür seçimlerden hemen sonra yayınlanmıştır. Tarih değişmiş

\footnotetext{
${ }^{7}$ Demokrat Parti'nin iktidara geldikten sonra seçim afişlerinde diğer partilerin adaylarının resmedilmesini yasaklaması belki de Menderes'in kadın olarak resmedilmekten hoşlanmadığının bir göstergesi olarak algılanabilir.
} 
ve artık vatandaşları temiz bir sayfa beklemektedir. Ancak karikatürün resme döktüğü vatandaşlar erkeklerden oluşmaktadır. Burada kadın figürünün olmaması aslında siyasi hayatın erkeklere ait bir dünya olduğunun da göstergesidir. 10 numaralı karikatür ise CHP'lileri resmetmiştir. Türkiye'nin farklı yörelerinden kıyafetler taşıyan bu karakterlerin hepsi erkektir. Karikatür bir insan selinden oluşmaktadır ve bu insan selinde gürbüz, güçlü erkekler yer almakta ancak kadınlara yer verilmemektedir.

Kadınların insan haklarına dayalı siyasal hakları gazetelerdeki karikatürlerde gündeme getirilmemiş yurttaş olma hali erkeklerle özdeşleştirilmiştir. Bu durumun oluşmasında dönemin siyasal hayatı içinde geride kalan apolitik kadın imajı ve buna bağlı olarak bilinç altında yer etmiş politik özneler olarak erkeklerin olduğu düşüncesi yatmaktadır. Kadınların sadece soyut kavramlarla resmedilmesi kadının siyasal hayatta bir aktör olarak görülmediğinin de en önemli kanıtlarından biridir. Dönemin en belki de tek dikkat çeken kadın siyasetçisi olan Halide Edip Adıvar'ın bu karikatürlerde yer almaması aslında kadınların münevver/makbul yurttaşlar olarak görüldüğü ve kadın kimlikleri ile kamusal ve siyasal alanda görünür olmadıklarının bir göstergesidir.

\section{SONUÇ}

Karikatür, tüm dünyada olduğu gibi Türkiye'de de mizah, hiciv ve muhalefetin bir ürünü olarak karşımıza çıkmaktadır. Ancak editoryal karikatür olarak ele aldığımız gazetelerin genellikle ana sayfasında çıan ve gündelik siyasi haberleri değerlendiren/anlamlandıran çizimler, karikatürün eleştiri yönünü gazetenin görüşüne göre şekillendirerek bağımsızlığını kaybetmesine neden olmaktadır.

Kadın çizimlerinin yer aldığı seçime yönelik karikatürlere baktığımızda kadın figürünün kullanılma amacı çoğunlukla gazetenin anlatılmak istenen düşünceyi (arzu eden/siyasetçi/erkek ve arzulanan/iktidar/millet vb. gibi/kadın) kadın erkek ilişkileri üzerinden daha etkileyici bir şekilde aktarabileceği fikridir. Burada gösterilmeyen ancak incelenen diğer karikatürlerde daha çok erkekler yer almakta ve konuşmakta, seçmen/yurttaş olarak gösterilmektedir. Aslında siyasette kadın figürünün genellikle soyut ve evrensel kavramlar için kullanıldığı görülmektedir. Amerika Birleşik Devletleri'nin simgelerinden biri olan ve liberalizmin "özgürlük" ilkesini vurgulayan "Özgürlük Heykeli", Yunan mitolojisindeki adalet ve düzen tanrıçası olan Themis'in sembolleştiği "Adalet Heykeli" ya da Fransız İhtilali'nin sembollerinden biri haline gelmiş "Halka Yol Gösteren Özgürlük" adlı resimde özgürlüğü temsil eden kadın figürü, kadınların siyasal anlamda sembolleştiği eserlerdir. Dünyadaki bu örnekler kadının idealize edilmiş hallerinden biri olarak yorumlanabilir. Kadına atfedilen saflık ve vicdanlı olma hali adalet ve özgürlük gibi ideallere yakıştırılan özelliklerdir. İncelenen karikatürlerdeki kadınların benzer şekilde "Türkiye", "zaman" ya da "demokrasi" gibi kavramlarla özdeşleştirilmesi kadına ait olduğu düşünülen anaçlık, masumluk ve duygusallık gibi özelliklerin karikatüristler tarafından dışavurumu olarak yorumlanabilir.

Dönemin genel özellikleri göz önüne alındığında Türkiye'nin bir geçiş döneminde olduğunu söyleyebiliriz. Soğuk Savaş döneminin etkisiyle liberalizm ve 
özgürlük düşüncesinin yaygınlaştığı ülkede devletçilik ilkesinin olumsuzlanıp demokrasi idealinin ön plana çıkarıldığı gözlemlenmektedir. Karikatürlerde ise durum çok farklı değildir. Batı tipi modernleşmenin kentlerde yaygınlaşması ile birlikte karikatürlerde de kentli kadın ve erkek figürleri demokrasi ve özgürlük konuşmaları yapmaktadir.

Karikatürlerde kadınlar genellikle modern ve idealize edilmiş kadın karakterine uygun olarak resmedilmiştir. Geleneksel ataerkil sistemin tercih edilen mazbut ve mutaassıp kadın figürleri yerine erkeği seçen/aldatan/ terk eden/cazibeli ve modern giyimli kadınlar olarak resmedilmesi aslında modern kent yaşamında kadınının daha güçlü bir karakterle karşımıza çıkmasına neden olmuştur. Ancak resmedilen kadınların hiçbiri siyasi bir figür değildir. Kadınlık, Berktay'ın da dile getirdiği gibi, "yalnızca norm sayılan erilliğe göre ve onunla ilişki içinde tanımlanır, kendi içinde özerk bir varlık olarak değil! Erkeğin düşünmeyi, aklı, kültürü̈ ve uygarlı̆̆ı temsil etmesine karşılık kadın, duyguları, bedeni, maddeyi; rasyonel olana karşılı irrasyonel olanı; bilinebilir olana karşılık bilinemez olanı; varlığa karşılık yokluğu temsil eder" (Berktay, 2010). Kadınların sadece erkeklerle birlikteyken karikatürlerde yer alması, erkeklerin söylemek ya da yapmak istedikleri çizilirken kadınının bir nesne olarak kullanılması ya da bir erkeği aşağılamak için kadın olarak tasvir edilmesi, kadının ataerkil ideolojinin yarattığı dünyada "öteki" olduğunun ve özne olarak algılanmadığının bir göstergesidir.

Dönemin editoryal karikatürleri (ve buna bağlı olarak gazeteleri) siyasi hayatta kadınları özne olarak görmemektedir. Kadınlar sadece soyut ya da arzulanan - bu bağlamda da edilgen- olarak resmedilmiştir. Siyasi alandaki erkek egemenliğinin dönemin en yaygın kitle iletişim aracı olan gazetelerde de kendini göstermesi kadınların kamusal alanda temsilinin aktif değil de pasif yurttaşlık üzerinden kabul gördüğünün de bir kanitı olarak kabul edilebilir.

\section{KAYNAKÇA}

Abadan-Unat N., Söylemden Protestoya: Türkiye'de Kadın Hareketlerinin Dönüşümü, 75 Yılda Kadınlar ve Erkekler, İstanbul: Tarih Vakfı Yayınları, 323-336.

Balcıoğlu, S. ve Öngören, F. (1973). 50 yılın Türk Mizah ve Karikatürü (cilt. 4). Türkiye İş Bankası Kültür Yayınları.

Berktay, F (1998). Cumhuriyetin 75 Yıllık Serüvenine Kadınlar Açısından Bakmak, 75 Yılda Kadınlar ve Erkekler, İstanbul: Tarih Vakfı Yayınları, 1-11.

Berktay, F. (2010). Felsefeyi "Öteki"ne açmak..., Bianet, 15 Mayıs 2017 tarihinde https://bianet.org/kadin/diger/120619-felsefeyi-oteki-ne-acmak adresinden erişildi.

Donovan, J. (2014). Feminist Teori. İstanbul: İletişim Yayınları.

Erdem, M. (2007). Kültür, Siyaset ve Karikatür: Temsil, Güç ve Direniş., Medya ve Siyaset Uluslararası Sempozyumu, İzmir, 180-190.

Higonnet A.(2005), Kadınlar, Tasvirler ve Temsil, Kadınların Tarihi. V. Cilt: Yirminci Yüzyılda Kültürel Bir Kimliğe Doğru (Fethi A. çev.). İstanbul: İş Bankası Yayınları, 312-366.

Öngören, F. (1998). Cumhuriyet'in 75. Yııında Türk Mizahı ve Hicvi. Ankara: Türkiye İş Bankası Kültür Yayınları. 
Saktanber, A. (1993). Türkiye'de Medya'da Kadın: Serbest Müsait Kadın veya İyi Eş Fedakar Anne, 1980'ler Türkiye'sinde Kadın Bakış Açısından Kadınlar(Tekeli Ş.. Yay. Haz.). İstanbul: İletişim Yayınları, 211-232.

Sledziewski G. E. (2005). Dönüm Noktası Olarak Fransız Devrimi. Kadınların Tarihi. IV. Cilt: Devrimden Dünya Savaşına Feminizmin Ortaya Çıkışı(Fethi A. çev.). İstanbul: İş Bankası Yayınları, 39-51.

Streicher, L. H. (1967). On A Theory of Political Caricature. Comparative Studies in Society and History, 9(04), 427-445.

Şenyapılı, Ö. (2003). Karikatür: neyi, neden, nasıl anlatıyor: kim, niye çiziyor!?. Ankara: ODTÜ Geliştirme Vakfı Yayıncılık ve İletişim.

Touraine, A. (2007). Kadınların Dünyası (Mehmet Moralı çev.). İstanbul: Kırmızı Yayınları.

Ülkü G.(2004)., "Söylem Çözümlemesinde Yöntem Sorunu ve Van Dijk Yöntemi”, Haber, Hakikat ve İktidar İlişkisi (Dursun Ç. Der.). Ankara: Elips Yayınları.

Yeni Asır Gazetesi (1 Ocak -15 Mayıs 1950)

Ulus Gazetesi (1 Ocak -15 Mayıs 1950)

Demokrat İzmir Gazetesi (1 Ocak -15 Mayıs 1950)

Vatan Gazetesi (1 Ocak -15 Mayıs 1950) 